\title{
Review
}

\section{Omeka Classic vs. Omeka.net}

Omeka is a free open-source web publishing platform and content management system used to showcase online collections and create digital exhibits. There are three versions of Omeka_Omeka.net, Omeka Classic, and Omeka S—and each differs in functionality and purpose. Omeka.net and Omeka Classic allow users to create websites to share their digital collections and exhibits online (Omeka.org, n.d.-a). Alternatively, Omeka S is a web publishing platform developed for institutions that want to collaboratively create collections and exhibits with a shared pool of online resources (Brett, 2018a). Omeka S websites require more resources, effort, and attention than the other versions of Omeka because they must be built from scratch and require additional time and planning (Brett, 2018b). Unlike Omeka S, Omeka Classic and Omeka.net provide users with various website themes. Due to my lack of experience using Omeka S, I will only evaluate Omeka.net and Omeka Classic.

Over the past year, I have been using Omeka.net and Omeka Classic for several projects in my role as a Student Library Assistant in the Faculty of Information and Media Studies (FIMS) at Western University. These projects include creating a digital photo archive for the FIMS graduating class photos, maintaining and updating the FIMS Graduate Library's special collections website, and creating an archival website for the Smoke Signals Radio Archive Project. While using these two Omeka versions, I noticed several differences between them despite their shared purpose. This review of Omeka Classic and Omeka.net outlines the similarities and differences between the two 
versions. I compare four factors: cost, storage, customization, and maintenance, to help future users decide which one best fits their needs.

\section{Cost}

Omeka Classic is a free option that requires users to handle all installations and updates, and to find a server that meets specific system requirements to host their site (Brett, 2018). However, Omeka.net handles all installations and updates, and it hosts its users' sites for a yearly fee (The College of Wooster Libraries, 2020). Omeka.net is the only option that requires users to pay for an Omeka plan in order to use the platform. There are four Omeka.net annual plans to choose from: Plus (\$35), Silver (\$75), Gold (\$350), and Platinum (\$1000) (Omeka.net, 2020b). Each plan offers a sliding scale of available features such as the amount of GB storage, the number of themes and plugins, and the number of websites users can create.

\section{Storage}

Storage is an important factor to consider, especially if collections are anticipated to grow or if users do not want to sacrifice the file quality of their items. Omeka Classic requires users to supply their own server (Omeka.net, 2020a). Therefore, the available storage depends on the server they use to host their website. Storage availability for Omeka.net users varies by plan (Omeka.net, 2020a). It is also worth noting that the maximum file size that can be uploaded directly on Omeka.net is 64MB (Omeka.net, 2020a). Files that exceed $64 \mathrm{MB}$ will need to be compressed, which will compromise the files' quality. 


\section{Customization}

Both Omeka.net and Omeka Classic allow website customization by offering various plugins and themes. Plugins are tools that allow users to "extend the basic functionality" (Omeka.org, n.d.-b, par. 1) of their website, whereas themes determine the look and alter the layout of the public facing website (Omeka.org, n.d.-c). While working with Omeka.net and Omeka Classic, I noticed that Omeka Classic offers more flexibility to customize websites, with 11 themes and more than 50 plugins. Users have the choice to configure the theme three different ways: in the admin dashboard, by using the CSS plugin, or by editing the themes' cascading style sheets (CSS) and hypertext preprocessor (PHP) files. However, for Omeka.net, the number of plugins and themes available varies by plan. Even with the most expensive Platinum plan, Omeka.net users have access to 11 themes, but only 32 plugins (Omeka.net, 2020b). Additionally, users can only configure certain elements of their theme by using the CSS plugin (which is only available for three out of the four plans) or directly through the administrator end of the site.

\section{Maintenance}

Lastly, it is also important to consider website maintenance when deciding between Omeka Classic and Omeka.net. Omeka Classic websites are more difficult to manage and maintain because users are responsible for all updates and installations (The College of Wooster Libraries, 2020), whereas Omeka.net maintains and handles all updates and installations for its users (The College of Wooster Libraries, 2020). Therefore, users should consider resources available to them when deciding which version of Omeka is a better fit. 


\section{Final Thoughts}

Omeka Classic is a free option that gives users more flexibility to customize sites and has no storage cap. However, Omeka Classic users are also expected to have access to a server that meets the system requirements to host their site, and users are fully responsible for all installations and updates of the software. On the other hand, Omeka.net does not require users to have access to a server to host their site, and they are not required to maintain the software with installations and updates. The yearly fee requirement covers this infrastructure support. Overall, the decision to choose between Omeka Classic and Omeka.net depends on user needs along with access to monetary and infrastructure resources.

Jasmine $L i$

Li, J. (2020). Omeka Classic vs. Omeka.net. Emerging Library \& Information

Perspectives, 3, 232-236. https://doi.org/10.5206/elip.v3i1.8625 


\section{References}

Brett, M. (2018a, May). Difference between Omeka Classic and Omeka S. [Online Forum post]. Omeka.org. https://forum.omeka.org/t/difference-between-omekaclassic-and-omeka-s/6197

Brett, M. (2018b, July). Omeka frequently asked questions. [Online forum post]. Omeka.org. https://forum.omeka.org/t/omeka-frequently-asked-questions/6777

The College of Wooster Libraries. (2020). Getting started with Omeka: Omeka.org vs. Omeka.net. Retrieved May 30, 2020, from https://libguides. wooster.edu/c.php?g=629900\&p=4396942

Omeka.org. (n.d.-a). Home. Retrieved May 30, 2020, from https://omeka.org/

Omeka.org. (n.d.-b). Omeka Classic user manual: Installing a plugin. Retrieved May 30, 2020, from https://omeka.org/classic/docs/Admin/Adding and Managing Plugins/\#installinga-plugin

Omeka.org. (n.d.-c). Omeka Classic user manual: Installing a theme. Retrieved May 30, 2020, from https://omeka.org/classic/docs/Admin/Appearance/Themes/

Omeka.net. (2020a). About. Retrieved May 30, 2020, from https://info.omeka.net/about/

Omeka.net. (2020b). Pricing. Retrieved May 30, 2020, from https://www.omeka.net/signup 